Saeculum Christianum

t. XXVII $・ 1 / 2020$

s. $106-117$

\title{
TOMASZ MAKOWSKI ${ }^{1}$
}

Wydział Nauk Historycznych

Uniwersytet Kardynała Stefana Wyszyńskiego w Warszawie

ORCID: 0000-0003-0623-2614

\section{WSTĘPNE ROZPOZNANIE RECEPCJI POLSKIEJ KSIĄŻKI DRUKOWANEJ W RENESANSOWEJ ANGLII NA PODSTAWIE POŚMIERTNYCH SPISÓW MAJĄTKU}

\section{Preliminary recognition of the reception of Polish books in Renaissance England \\ Abstract}

The author assumes the presence of books by Polish authors in the libraries of Renaissance England on the basis of certified ownership of copies of their publications in over three hundred inventories of private English libraries from the times of the Tudors and the first Stuarts. So far, in a small number of scientific publications, conclusions have been drawn from preserved copies of books by Polish authors currently held in English libraries. The question of what influence the books of Polish authors had on the minds of the English during the Renaissance must remain at this stage of research without a full answer. There were the most important books of Polish authors published in Latin in English libraries, but proving their real impact requires further research on the 16th-17th century book collections.

Keywords: Book, England, libraries, Polish authors, Stanisław Hozjusz

\section{Streszczenie}

Autor wnioskuje na temat obecność polskich autorów w bibliotekach renesansowej Anglii na podstawie poświadczonej własności egzemplarzy ich publikacji w ponad trzystu inwentarzach prywatnych bibliotek angielskich z czasów Tudorów i pierwszych Stuartów. Dotychczas w nielicznej literaturze naukowej wnioskowano z zachowanych egzemplarzy książek polskich autorów obecnie znajdujących się w bibliotekach angielskich. Pytanie, jaki wpływ wywarły książki polskich autorów na umysły Anglików w czasach renesansu, musi pozostać na tym etapie badań bez pełnej odpowiedzi. Występują w bibliotekach angielskich

\footnotetext{
1 Dr Tomasz Makowski - dyrektor Biblioteki Narodowej, przewodniczący Krajowej Rady Bibliotecznej, wiceprzewodniczący Polskiego Komitetu Programu UNESCO „Pamięć Świata”, od 1995 r. zatrudniony na UKSW, obecnie w Katedrze Historii Książki, Bibliotek i Archiwów. Specjalizuje się w historii bibliotek i książki. Autor czterech książek i kilkudziesięciu artykułów naukowych.E-mail: t.makowski@bn.org.pl.
} 
najważniejsze książki polskich autorów wydane po łacinie, ale udowodnienie ich realnego wpływu wymaga dalszych badań nad inwentarzami księgozbiorów z XVI-XVII w.

Słowa kluczowe: książka, biblioteki, Anglia, autorzy polscy, Stanisław Hozjusz

$\mathrm{K}$ ontakty polsko-angielskie, a zwłaszcza wizerunek Polski w oczach mieszkańców Anglii, w omawianym czasie były przedmiotem studiów Henryka Zinsa, prof. UMCS w Lublinie. Dużo miejsca poświęcił on kontaktom intelektualnym Polski i Anglii w rozprawie Polska w oczach Anglików XIV-XVI wiek, wydanej w 1974 r., a wznowionej w 2002, choć niestety niemal bez aktualizacji treści ${ }^{2}$. Chociaż opublikowano dość dużo opracowań historycznych dotyczących stosunków polsko-angielskich w okresie nowożytnym, badań nad znajomością polskiej książki drukowanej w Anglii właściwie nikt systematycznie nie prowadził. O recepcji w innych krajach europejskich też niewiele wiadomo. Jedyna dotychczas analiza udziału polskich autorów w lekturach mieszkańców renesansowej Anglii znajduje się w pracy Henryka Zinsa.

Jak podaje Henryk Zins, najpopularniejszym autorem w bibliotekach średniowiecznych jest bez wątpienia Marcin Polak. Jego Chronicon pontificum et imperatorum występuje w wielu księgozbiorach. Na informacjach w nim podanych opierają się angielskie kroniki, np. Compilatio sive chronicon de regne et gestis Britonum et Anglorum ... czy kronika opata Thomasa Burtona. Nie mniejszą popularnością cieszyło się jego dzieło prawnicze Margarita decreti. Innym popularnym autorem był Ślązak Witelo (ok. 1230 - ok. 1314). Jego dzieła o optyce można znaleźć w wielu bibliotekach XIV w. Listę autorów średniowiecznych należy zakończyć Mateuszem z Krakowa świetnie znanym w średniowiecznej Anglii, a także poza nią ${ }^{3}$.

Na podstawie 137 poloników odnalezionych w katalogu Biblioteki Bodlejańskiej w Oksfordzie z 1620 r. Zins stwierdził, iż najpoczytniejszymi autorami renesansowymi byli: bp Marcin Kromer (jedenaście egz., w tym cztery De origine et rebus gestis Polonorum), Aleksander Gwagnin (siedem egz., w tym dwa Sarmatiae Europeae descriptio i dwa Moscoviae descriptio), Krzysztof Warszewicki (siedem egz. dzieł różnych, brakuje najpopularniejszego w Polsce Rerum polonicarum libri tres i De optimo statu libertatis), Maciej z Miechowa (pięć egz., w tym trzy Tractatus de duabus Sarmatiis, Asiana et Europiana i po jednym Chronica Polonorum i De Moscovia), Stanisław Orzechowski (pięć egz., m.in. Fidei catholicae confessio, De lege coelibatus... oratio), Andrzej Frycz Modrzewski (cztery egz., w tym jeden Commentariorum de Republica emendanda libri quinque), Jan Zamoyski (cztery egz.), Andrzej Wolan (cztery egz.), Faust Socyn (cztery egz.), Mikołaj Kopernik (trzy egz. De revolutionibus...), Jost Ludwik Decjusz (trzy egz.), Wawrzyniec Korwin (trzy egz.), Jan Łasicki (trzy egz.), Erazm Ciołek (trzy egz.). Katalog zawiera też po dwa dzieła kard. Stanisława Hozjusza, Jana Łaskiego młodszego, Leonarda Goreckiego, Jakuba Górskiego, Stanisław Sokołowskiego i Jana Herburta. Zins konkluduje: „w Bodleian Library w Oksfordzie znajdowała się dosyć bogata kolekcja dzieł znacznych autorów polskich epoki

H. Zins, Polska w oczach Anglików, XIV-XVI wiek, wyd. 2 popr., Lublin 2002.

Ibidem, s. 148-150. 
odrodzenia, zawierająca wiele najważniejszych łacińskich tekstów historycznych, prawnych, religijnych i literackich, jakie powstały w XVI w. w Polsce"4.

Jako drugą co do zasobności w polonika bibliotekę Zins podaje prywatny księgozbiór lorda Johna Lumleya (ok. 1534-1609), w którym na 2609 pozycji 40 jest polskiego autorstwa: pojedyncze dzieła historyków i humanistów, zaś najwięcej sześć tytułów autorstwa kard. Stanisława Hozjusza i dwa znanego teologa Stanisława Sokołowskiego 5 . Ponadto notuje mniejsze biblioteki. I tak w bibliotece katedralnej w Ripon sześć poloników (wszystkie teologiczne, w tym dwa Hozjusza), w bibliotece kolegium Corpus Christi na pięć poloników cztery Hozjusza, w bibliotece uniwersytetu w Edynburgu na trzy polonika dwa Hozjusza. Ten fragment zakończony jest konkluzją: „Marcin Polak należał do najlepiej reprezentowanych w bibliotekach angielskich epoki odrodzenia autorów polskich, obok niego należy wymienić Stanisława Hozjusza, Marcina Kromera i Aleksandra Gwagnina, w dalszej kolejności Macieja Miechowitę, Mikołaja Kopernika, Andrzeja Frycza Modrzewskiego"ø.

Rozpoznanie faktycznej poczytności autora lub dzieła na podstawie zachowanych egzemplarzy jest od początku obarczone błędem. Fakt zachowania do czasów obecnych egzemplarzy, a co za tym idzie tytułów konkretnych dzieł, można uzasadnić brakiem zainteresowania ze strony właścicieli i czytelników, czyli niezniszczeniem fizycznym - co często zdarzało się dziełom popularnym. Dziełom niechcianym lub przypadkowo darowanym zaczytanie nie groziło. Dzieła zamawiane i kupowane przez właściciela księgozbioru, a omawiane tu czasy to czasy drogich książek, sprzed wprowadzenia taniego papieru w XIX w., były zazwyczaj przez niego czytane i wykorzystywane w profesjonalnej działalności lub były wyrazem osobistych zainteresowań - ich lektura sprawiała mu przyjemność.

O recepcji książki najczęściej wnioskuje się właśnie na podstawie zachowanych egzemplarzy. Czy o wpływie polskich autorów na umysły Anglików w renesansie świadczą zachowane XV- i XVI-wieczne druki obecnie znajdujące się w bibliotekach Wielkiej Brytanii? Jak zostanie wykazane w niniejszym artykule, o wpływie konkretnego pisarza nie świadczą jego zachowane dzieła.

Nie można się zgodzić ze słowami prof. Henryka Zinsa: „Bodleian Library oraz biblioteka lorda Lumleya to dwie najważniejsze w Anglii epoki odrodzenia kolekcje poloników. Liczba dzieł autorów polskich, znajdujących się w innych bibliotekach, była minimalna"”.

Spisy książek można znaleźć w różnego rodzaju dokumentach, w tym testamentach, spisach wydatków i rejestrach donacyjnych. W Anglii od 1521 r. majątek osoby zmarłej winien być spisany i złożony w odpowiednim urzędzie. Mimo że egzekucja tego prawa była niekonsekwentna i nigdy nieujednolicona to jednak do połowy wieku siedemnastego powstały tysiące spisów, w tym również książek. Jest to nie tylko bezcenne jedyne źródło historyczne o dawnych bibliotekach prywatnych, ale także o książkach, które nie dotarły do czasów obecnych. Żałować należy, że taki obowiązek nie był wprowadzony w Polsce, przez co cierpi wiedza o dawnych polskich księgozbiorach, zwłaszcza wobec zniszczeń nie tylko oczywistych wynikających z upływających lat jak zaczytanie, pożar, kradzieże, brak dbałości, ale także nadzwyczajnych jak wojenne kradzieże, konfiskaty po powstaniach

\footnotetext{
Ibidem, s. 152-154.

Ibidem, s. 155-156.

Ibidem, s. 156-157.

Ibidem, s. 156.
} 
niepodległościowych, ale przede wszystkim hekatomba drugiej wojny światowej, podczas której okupanci niemieccy i sowieccy zniszczyli ok. 70\% zasobów polskich bibliotek.

Sears Jayne w książce Library Catalogues of the English Renaissance 8 cytuje 574 katalogi prywatnych bibliotek. Jest to liczba zaniżona wobec przyjęcia przez autorkę kryterium 15 lub więcej książek jako biblioteki, o czym po części też świadczy fakt, że wymienione biblioteki w 2/3 znajdowały się w Oksfordzie i Cambridge 9 . Imponujące dzieło badaczki amerykańskiej, wznowione w 1983 r., opatrzone znakomitym wstępem pozostaje nadal aktualnym przewodnikiem po księgozbiorach renesansowej Anglii.

W 1986 r. Elisabeth Leedham-Green z uniwersytetu w Cambridge wydała dwutomowe dzieło Books in Cambridge Inventories: Book-lists from Vice-Chancellor's Court Probate Inventories in the Tudor and Stuart Periods obejmujące 200 inwentarzy ${ }^{10}$. Tom pierwszy zawiera edycje inwentarzy bez identyfikacji poszczególnych pozycji. W tomie drugim w układzie alfabetycznym autorów lub tytułów autorka ukazała faktyczny zasób bibliotek. Pod nazwiskiem konkretnego autora podaje informacje, w którym inwentarzu znajduje się dana pozycja. Cytuje również zapiskę inwentarzową, co znacznie ułatwia korzystanie ze spisu. Całość uzupełniają ekstrakty z 41 testamentów zawierające informacje o książkach.

W 1992 r. prof. Robert J. Fehrenbach z College of William and Mary w Williamsburgu i dr E.S. Leedham-Green wydali pierwszy tom, z planowanych siedmiu, Private Libraries in Renaissance England. A Collection and Catalogue of Tudor and Early Stuart Book-Lists ${ }^{11}$. Zamierzeniem wydawców było udostępnienie zachowanych inwentarzy księgozbiorów głównie uczonych i studentów z lat $1507-1653^{12}$. Pierwsze dwa tomy zostały mocno skrytykowane przez Nigela Ramsaya w recenzji w „The Library” w 1994 r. ${ }^{13}$ Z wieloma zarzutami recenzenta trudno się nie zgodzić. Jakkolwiek dla badacza zainteresowanego recepcją polskiej książki poza granicami Rzeczypospolitej publikacja ta jest źródłem pierwszorzędnym.

Podstawą wnioskowania na temat obecności polskich autorów, zaprezentowanego w niniejszym artykule, są poświadczona własność egzemplarzy ich dzieł w ponad trzystu inwentarzach prywatnych bibliotek angielskich z czasów Tudorów i pierwszych Stuartów. Wydaje się, że stanowią reprezentatywną grupę będącą wiarygodną podstawą źródłową, choć jedynie jako wstępne rozpoznanie tematu. Krótki pobyt autora w Wielkiej Brytanii ${ }^{14}$

\footnotetext{
S.R. Jayne, Library Catalogues of the English Renaissance, Berkeley-Los Angeles 1956.

9 Dzięki pomocy wielu bibliotekarzy w Wielkiej Brytanii powstał spis 848 inwentarzy bibliotek z lat 1500-1640. Wśród nich 59 dotyczyło Uniwersytetu w Oksfordzie, 65 w Cambridge, 150 innych bibliotek instytucjonalnych, największa grupę stanowiły 574 inwentarze bibliotek prywatnych. Ciekawie układa się podział według kryterium czasowego: z 1. 1500-1550 pochodzą 244 inwentarze, 1550-1600 - 314, 1600-1640 - 290.

10 E. Leedham-Green, Books in Cambridge Inventories: Book-lists from Vice-Chancellor's Court Probate Inventories in the Tudor and Stuart Periods, Cambridge 1986. Zob. rec. Kennetha Humphreysa w „The Library”, sixth series, 10/1988, no 1, s. 55-58.

11 R.J. Fehrenbach, E. Leedham-Green, Private Libraries in Renaissance England. A Collection and Catalogue of Tudor and Early Stuart Book-Lists, t. 1, 1992; t. 2, 1993; t. 3, 1994; t. 4, 1995, t. 5, 1998. Pierwsze cztery tomy z adresem wydawniczym „Binghampton, New York”, ostatni tom zaś z adresem „Tempe, Arizona”. Do przebadania pozostają jeszcze t. 6-9 wydane w latach 2004-2017.

12 O historii projektu badawczego zob. E.S. Leedham-Green, Private Libraries in Renaissance England: A Progress Report, „The Papers of the Bibliographical Society of America”, 91/1997, no 4, s. 563-571.

13 „The Library. The Transactions of the Bibliographical Society”, sixth series, 16/1994, no 3, s. 242-244.

14 Trzytygodniowy pobyt został sfinansowany z badań własnych przyznanych przez Uniwersytet Kardynała Stefana Wyszyńskiego w Warszawie.
} 
nie pozwolił na rozszerzenie badań na inne drukowane inwentarze oraz dużą wciąż grupę rękopiśmiennych spisów.

Bezwzględnie, autorem najczęściej wymienianym w zbadanych inwentarzach jest kardynał Stanisław Hozjusz, sekretarz króla Zygmunta Starego, biskup chełmiński i warmiński, kardynał penitencjarz większy, jeden z czołowych teologów kontrreformacji. Aż 20 egzemplarzy jego dzieł zanotowano w badanych inwentarzach. Potwierdza to opinię o wadze, jaką przywiązywano do dzieł wybitnego katolickiego teologa i polemisty. Kardynał Hozjusz nie tylko utrzymywał w Rzymie liczne kontakty z angielskimi katolikami Europie, a właściwie utrzymał z nimi stosunki od swoich studiów w Padwie, ale także wysyłał im swoje publikacje oraz był tłumaczony na język angielski. Sam znał również literaturę angielską. W samej Anglii był przedmiotem polemik jako jeden z głównych przedstawicieli kontrreformacji15.

Według Leedham-Green pięć egzemplarzy dzieł jego autorstwa posiadał Andrew Perne: zapewne 2 wydania Opera omnia „Hosij opera Fol.” „Iterum Idem Fool. [!]”, Confutatio prolegomenon Brentii „contra Brentium”, De expresso Dei verbo „Hosius De expresso Dei verbo 160" i Epistolae duae insignes, altera D.S. Hosii, altera M. Cromeri „Epistole due"16. Wydaje się, że Perne chciał mieć najważniejsze prace tego autora. W tym zestawieniu brakuje pracy najważniejszej i najczęściej wydawanej w Europie, czyli Confessio catholicae fidei Christiana. Sądzę, że Perne jednak ją posiadał. W inwentarzu znalazły się dwie pozycje „,confessio catholica fo.”, a niżej „confessio polonica fo.”' ${ }^{\prime 7}$. Według Leedham-Green pozycja pierwsza oznacza Confessio Catholicae fidei Christiana, Petrikoviae ${ }^{18}$, a druga Confessio fidei, quam Ferdinando obtulerunt barones, quae et Maximiliano II et regi Poloniae Sigismundo oblata est... fo. $1573^{19}$. Wydaje się jednak, że „confessio catholica fo.” to raczej dzieło Hozjusza pod znanym tytułem, zaś „,confessio polonica fo.” to właśnie confessio piotrkowskie. Sprawa ta wymaga jednak dalszych badań.

Trzy egzemplarze dzieł Hozjusza odnotowano w bibliotece Richarda Coxa (1500-1581), kanclerza Uniwersytetu w Oksfordzie i biskupa Ely, „ważnej postaci wśród angielskich reformatorów” (t. 1, s. 3). Wśród 196 woluminów znalazły się: „Hosii varia opera” (t. 1, s. 21), „Hoshius contra Brentium” (t. 1, s. 27), „Hosius contra hereses nostri temporis” (t. 1, s. 31). Żadna z pozycji wymienionych nie została przez edytorkę E.S. Leedham-Green zidentyfikowana.

Dwa dzieła Hozjusza znalazły się w niedużej, liczącej 42 pozycje, bibliotece Nicholasa Sykesa pełniącego funkcję kamerdynera (butlera) w słynnym kolegium Christ Church w Oxfordzie (+1562): „Confessio Polonica”, czyli Confessio catholicae fidei Christiana. Edytor J.R. Romano z Uniwersytetu w Miami uzupełnił komentarzem: „Hozyusz defended the Catholic position and was known as a "hammer" of heretics” (t. 3, s. 72 71.18). Drugim dziełem było „Hosius contra Brechens”, czyli Confutatio Prolegomenon Brentii. Verae, Christianae, catholicaeque doctrinae solida propugnation (t. 3, s. 72 71.21). Warto zauważyć, iż

\footnotetext{
15 U. Szumska, Anglia a Polska w epoce humanizmu i reformacji. Związki kulturalne, Lwów 1938, „Prace historyczno-kulturalne", red. S. Łempicki, t. 5, s. 93-98. Temat obecności Hozjusza w Anglii wymaga osobnego omówienia, informacje tutaj podane są przyczynkiem do niego.

16 Fehrenbach R.J., E. Leedham-Green, op. cit., t. 1, s. 437.

17 Ibidem, s. 457.

18 Pod hasłem „Piotrków (Synod of)”. Ibidem, t. 2, s. 621.

19 Pod hasłem ,Poland”. Ibidem, t. 2, s. 633.
} 
przeważająca część książek z tej biblioteki dotyczy kontrowersji teologicznych. Tylko pięć z czterdziestu dwóch dotyczy tematyki innej niż teologiczna.

W liczącej około siedemdziesiąt pozycji bibliotece Alana Scotta $(\dagger 1578)$ rektora (provosta) Queen's College w Oksfordzie znalazły się dwa egzemplarze dzieła Hozjusza Confutatio Prolegomenon Brentii. Verae, Christianae, catholicaeque doctrinae solida propugnation: „hessius confutac” (t. 5, s. 287 136.22) i „Hossius confutacion” (t. 5, s. 288 136.31).

Jedno dzieło, na około sto w swoim księgozbiorze, posiadał John Badger, superior bedel w Divinity School w Oksfordzie (†1577): „confutatio hossii”, czyli Confutatio prolegomenon Brentii (t. 5, s. 16 115.23). Również jedno posiadał wykładowca tegoż uniwersytetu, James Reynolds, w swojej liczącej ok. 360 dzieł bibliotece: „Hossius de expresso Dei verbo”, czyli De expresso Dei verbo (t. 5, s. 135 127.211). To samo dzieło posiadał Richard Mote $(\dagger 1592)$ „Hosius de exp[re]ss[o verbo Dei]”"20. Opera omnia można było znaleźć także wśród książek Martina Parkinsona „hosij op[er]a”21 a Confessio catholicae fidei christianae u Johna Wellesa „Co[n]fessio hosij”22. Loci communes można było znaleźć w bibliotece Johna Stokesa „Loci co[mmun]es Hosij" ${ }^{23}$. Z powodu defektu inwentarza nie zidentyfikowano dzieła Hozjusza ,[] Hosij” występującego w anonimowym inwentarzu osoby zmarłej w 1588-1589 r. ${ }^{24}$ Księgozbiór ów był jednym z większych, obejmował ponad tysiąc woluminów.

Innym polskim autorem, którego dzieła odnaleziono w cytowanych inwentarzach, był Mikołaj z Błonia. W omawianych źródłach jest informacja o 6 egzemplarzach dzieł tego autora. Sermones znalazły się w bibliotece Roberta Hoopera, master of Balliol († 1570/71): „Sermones Nicholaii de bloni”25 i w bibliotece kaznodziei Johna Shaxtona (?1568-1600/1601): „Nicolai de Blony Sermones”26. W bibliotece Johna Hatchera znalazł się znany Tractatus sacerdotalis de sacramentis deque divinis officiis ,opus sup[er] s[acr]amentis Nich[ol]i”27. Wobec umieszczenia przez dr Leedham-Green tych dwóch ostatnich pod hasłem „Nicolaus de Blony”28, duże zdziwienie budzi umieszczenie przez nią osobno hasła „Plovius Nicolaus” i przypisanie mu Tractatus sacerdotalis. Według autorki znajdują się trzy egzemplarze tego dzieła u: Anon. 9 († przed 1558), „nicolaus de Plove”, Anon. 17 († przed 1558), ,nicolaus de ploro perdidum” i u Stephena Thompsona († 1598), Nicholaus de plore”. Z zapisu źródłowego jednak nie wynika, o jakie dzieła Mikołaja z Błonia chodzi. Identyfikacja ich jako Tractatus sacerdotalis wydaje się dyskusyjna ${ }^{29}$.

Zidentyfikowano cztery egzemplarze dzieł Marcina Kromera. Jeden znalazł się w bibliotece Philipa Johnsona. Zachowana w inwentarzu zapiska „Cromerus” nie pozwala

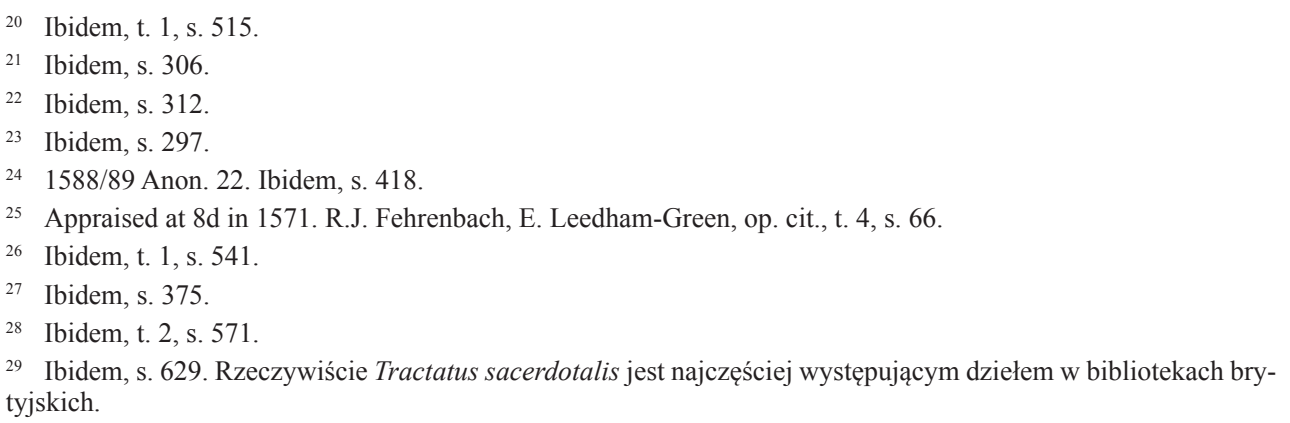


na wskazanie konkretnego dzieła ${ }^{30}$. Pozostałe trzy egzemplarze znalazły się w bibliotece Perne’a. Były to: De origine et rebus gestis Polonorum („Cromerus de origine polonorum fo.”), De vera et falsa religione... („Tromerus De religione vera et falsa bos 4o”) i Sermo de tuenda dignitate sacerdoti... (,Cromerus de coniugio sacerdotis...”) ${ }^{31}$.

Odnaleziono cztery egzemplarze Margarita decreti Marcina Polaka w bibliotekach: Johna Wyera „margarita decretor[um]”32, Anon. 6 († przed 1558) „margarita decreti”33, Anon. 9 († przed 1558) ,Margarita decreti”34, Anon. 17 († przed 1558), ,margarita decret[i]”35. U Perne’a znalazła się zapewne historia Marcina Polaka, sądząc z zapisu: „Mariani Scoti historia fo.”, którego tekst występował tylko z tekstem Marcina Polaka ${ }^{36}$.

Odnaleziono trzy egzemplarze De republica emendanda Andrzeja Frycza Modrzewskiego. Jeden w bibliotece Stanhope'a „Fricius de republica emendanda” (t. 1, s. 52 2.20) ${ }^{37}$, drugi w bibliotece Perne'a „Frisius De rep[ublica] fo." ${ }^{38}$, trzeci w bibliotece fellow w Cambridge Williama Lyffe’a (†1569) „Andreas phrisius de republica emendanda" 39 .

Odnaleziono trzy egzemplarze pracy Wawrzyńca Goślickiego De optimo senatore libri $d u o^{40}$. Jeden egzemplarz znajdował się w księgozbiorze Perne’a „Gruvalius De optimo senatore 4o"41, drugi u Richarda Mote’a (†1592) „Grimalius de optimo senatore"42. Ostatni egzemplarz znajdował się w posiadaniu Roberta Devereux earla Essex. Został zakupiony przez nauczyciela znanego arystokraty Roberta Wrighta w maju 1577 r. po przyjeździe do Cambridge „Grimalius De optimo Senatore"43.

Odnaleziono tylko dwa egzemplarze dzieła Mikołaja Kopernika De revolutionibus. Jeden w bibliotece Perne'a „Cop[er]nicus de Revolutionibus 4o”,44, drugi u Williama Balla $(† 1601)$, ,Copernicus ${ }^{\prime 45}$.

Odnotowano dwa egzemplarze dzieła Jana Łasickiego De Russorum Moscovitarum et Tartarorum religione, \&c. e diversis scriptoribus. Pierwszy znajdował się w bibliotece Perne'a „Russorum historia 4o”46, drugi u Edwarda Deringa „Johes Sacranus de erroribus Ruthenorum Spirae 1582 4to"47.

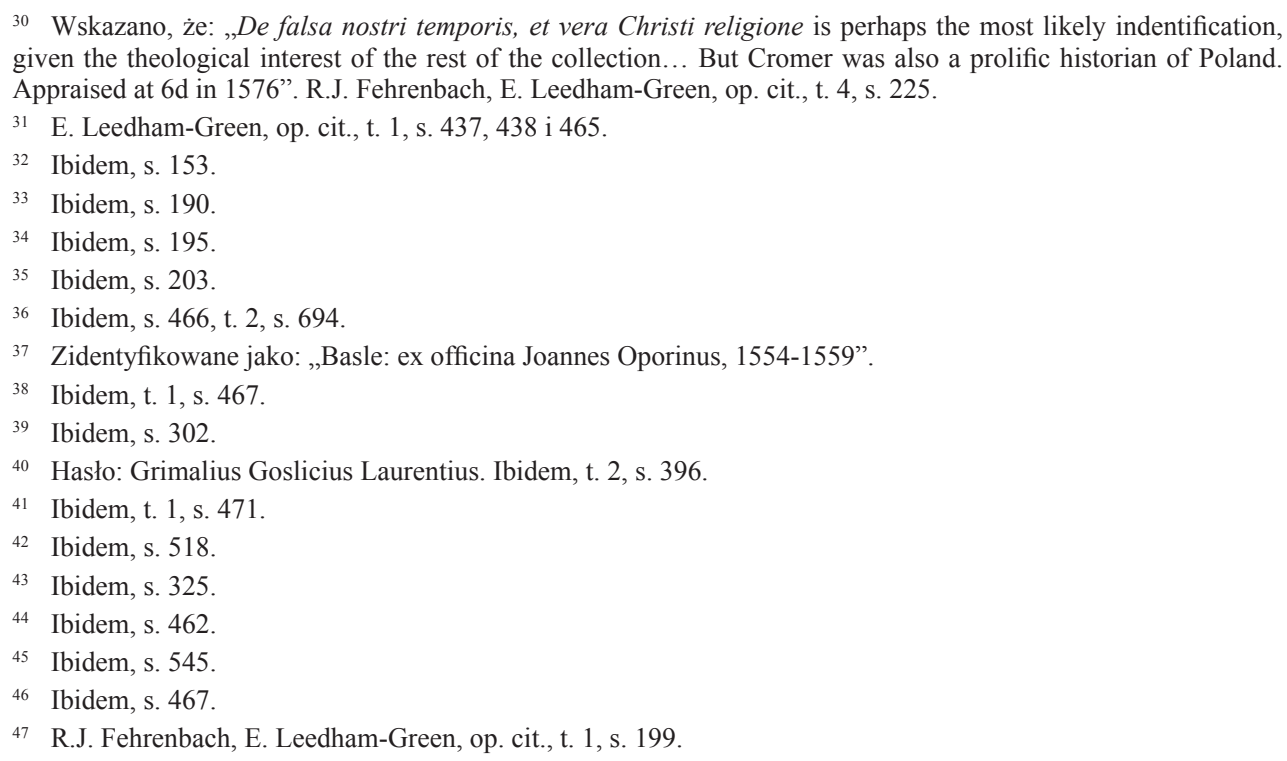


W bibliotece Edwarda Deringa znalazł się również „Valentinus Smalcius: examinatio centum errorum Martini Smiglecii Jesuitae Racoviae 1615" [Valentin Schmatz (Valentinus Smalcius). Examinatio centum errorum. Rakow: (stationer unknown), 1615] (t. 1, s. 239 $4.431)^{48}$. W jego bibliotece znalazł się także egzemplarz mowy Jerzego Ossolińskiego, posła polskiego w Anglii, późniejszego wielkiego kanclerza koronnego: „Two small bookes viz: one calld Hispanis reformatus and the other the polonians speech". Edytorki Nati H. Krivatsy i Laetitia Yeandle z Folger Shakespeare Library drugą książkę zidentyfikowały jako: „Perhaps Jerzy Ossolinski, Count. A true copy of the Latine oration of the excellent lord George Ossolinski. With the translation. London: [G. Purslowe] for W. Lee, 1621. STC 18890. Ossolinski was the Polish ambassador to England, and was identified in the Stationers Register entry of this work (5 April 1621, Arber 4:14) as the „Polonian Embassadour”. The published speech, containing only sixteen pages, might have been described as small [...] Cost with one other, 9d in 1621 (April 19)" (t. 1, s. 248 4.493:1).

W bibliotece Perne'a znalazło się wydane w 1551 r. w Bazylei dzieło Stanisława Orzechowskiego De lege coelibatus contra Syricium in concilio habita oratio, zapisane jako “Orichovius Stanislaus De lege coelibatus... Epistola de coelibatu. Również u Perne’a to samo wydanie „Stanislaus De celibatu bis 8o"49.

W bibliotece Johna Tathama ( $† 1576)$ znalazło się dzieło Jakuba Górskiego Commentariorum artis dialecticae libri decem ,gorsii dialec" ${ }^{\text {"50 }}$. W bibliotece Johna Glovera znalazła się Jeana de Montluca Epistola de Andium Duce in regnum Polonicorum ,epistola Monlucii ad Polonos" ${ }^{51}$. W inwentarzu biblioteki Alana Scotta jest nota „de sigismundo”, którą zidentyfikowano jako: „If the entry is descriptive of a title or subject, possibilities include Jodocus Ludovicus Decius, Contenta: de vetustatibus polonorum, 1521 (liber II: De rigismundi regis temporibus), and Johann Eck, Ad invictissimum poloniae regem sigismundum, 1526"52.

W inwentarzu biblioteki Stanhope'a odnaleziono zapis: „Puerilis institutio Sclavonice”, który Leedham-Green zidentyfikowała: w Trinity College Library znajdują się w kolekcji rękopisów pod sygnatura 803 trzy woluminy pochodzące z biblioteki Stanhope’a:

„1.A Slavonic Reading-Book? [...]

2. A Slavonic MS.

3. Printed. Nauka krocka [!] kuczytaniu [!] Pisma polskiego. Alphabet and a few Psalms and prayers. Full-page woodcut of a cock at the end"s3. Leedham-Green dodała do ustaleń Jamesa: „Königsberg: perhaps G. Osterberger, c. 1580”54. U Estreichera zaś notowany jest jako druk lwowski z 1599 r. w 80 kk. 10 (E XXIII, 62).

\footnotetext{
48 Według Urszuli Szumskiej Marcin Śmiglecki należy w Anglii do popularnych polskich autorów, obok Hozjusza i Goślickiego. U. Szumska, Anglia a Polska ..., op. cit., s. 102-103.

49 R.J. Fehrenbach, E. Leedham-Green, op. cit., t. 2, s. 585.

50 Zidentyfikowane jako: „Jakób Górski. Commentariorum artis dialecticae libri decem. Leipzig: in officina Voegeliana, 1563 (probable). VD 16 G2673. Appraised at 4d in 1576”. R.J. Fehrenbach, E. Leedham-Green, op. cit., t. 4 , s. 291.

51 Zidentyfikowane jako: „Jean de Montluc, Epistola de Andium Duce in regnum Polonicorum. Lusignan: excud. Ivo Durerius, 1573-1574. Appraised at 4d in 1578”. R.J. Fehrenbach, E. Leedham-Green, op. cit., t. 5, s. 240.

52 „Appraised at 6d in 1578”. Ibidem, s. 287.

53 M.R. James, The Western Manuscripts in the Library of Trinity College, Cambridge. A Descriptive Catalogue, vol. 2, Cambridge 1901, s. 250.

54 R.J. Fehrenbach, E. Leedham-Green, op. cit., t. 1, s. 51.
} 
Na podstawie zbadanych inwentarzy można stwierdzić, iż żaden z prywatnych posiadaczy książek w renesansowej Anglii nie był zainteresowany gromadzeniem książek autorów polskich. Brak również wskazówek, aby gromadzili dzieła autorów innych nacji ze względu na zainteresowanie konkretnym kręgiem kultury lub państwa. Wśród posiadaczy największej liczby książek polskich (22 egzemplarze) $)^{55}$ należy na pierwszym miejscu wymienić posiadacza największej prywatnej biblioteki w Anglii, teologa Andrew Perne'a (1519?-1589). Absolwent St. John's College w Cambridge, fellow tamże, a następnie w Queen's College. Był wicekanclerzem uniwersytetu oraz dziekanem w Ely i kanonikiem w Windsorze ${ }^{56}$. Znany był zarówno z największej prywatnej biblioteki w ówczesnej Anglii, jak również z radykalnych zmian poglądów zgodnie z bieżącą władzą ${ }^{57}$. Wydaje się, że jego szerokie zainteresowania są zrozumiałe i z tego powodu. W owym czasie jedynie księgozbiory znanego matematyka Johna Dee $(\dagger 1608)^{58}$ i lorda Lumleya $(\dagger 1609)^{59}$ mogły być porównywane $\mathrm{z}$ jego ${ }^{60}$. Cztery polonica posiadał sir Edward Dering pierwszy baronet Surrenden w Kent (1598-1644), polityk i kolekcjoner. Była to także jedna z największych angielskich prywatnych bibliotek, obejmująca około dwa tysiące książek. Pozostałe polonika występowały w bibliotekach angielskich bibliofilów w pojedynczych egzemplarzach.

Na pytanie, czy to aż czy tylko tyle książek, należy zdecydowanie wskazać, iż w XVI w. liczba poloników w bibliotekach wzrasta. W opublikowanych inwentarzach liczącej około półtora tysiąca pozycji bibliotece króla Henryka VIII jedynymi polonikami są dwa rękopisy Marcina Polaka Chronica pontificum et imperatorum trzynasto- i czternastowieczny, oba $\mathrm{z}$ angielskich skryptoriów ${ }^{61}$.

Oczywiście niektóre identyfikacje budzą zastrzeżenia. Częsty zapis „confessio fidei” zazwyczaj identyfikowany jest „Presumably one of the many published confessions of Protestant churches on the Continent”, gdy tymczasem może to być jeden z najpopularniejszych

\footnotetext{
55 Miał Kopernika, 3 dzieła Kromera: „Cromerus de origine polonorum fo.” [De origine et rebus gestis Polonorum], ,Tromerus De religione vera et falsa bos 4o” [De vera et falsa religione...], „Cromerus de coniugio sacerdotis...” [Sermo de tuenda dignitate sacerdoti...], Goślickiego De optimo senatore libri duo „Gruvalius De optimo senatore”, 5 egzemplarzy Hozjusza: „Hosij opera Fol.” „Iterum Idem Fol.”, Confutatio prolegomenon Brentii „,contra Brentium”, De expresso Dei verbo, Epistolae duae insignes, altera D.S. Hosii, altera M. Cromeri „Epistole due”, Jan Lasitzki De Russorum Moscovitarum et Tartarorum religione, \&c. e diversis scriptoribus $1582 \mathrm{w}$ bibliotece Perne'a 1589 „Russorum historia 4o”, Modrevius Andreas Fricius De republica emendanda libri quinque „Frisius De republica fo.”, Orichovius Stanislaus De lege coelibatus... Epistola de coelibatu „Stanislaus De celibatu bis 8o", Confessio Catholicae fidei Christiana, Petrikouiae Adams „,confessio catholica fo.”, Confessio fidei, quam Ferdinando obtularunt barones, quae et Maximiliano II et regi Poloniae Sigismundo oblata est... fo. „confessio polonica 4o”, Polonicae historiae corpus „Polonica historia fo.”, Possevino Moscovia et alia opera u Perne’a 2 egz. „Possevinus De statu seculi fol.” i „Possevinij opera fo.”, Alexander Guagninus Sarmatiae Europeae descriptio „discriptio Sarmatiae fo.”, Scotus Marianus Chronica. Adiecimus M. Poloni historiam „Mariani Scoti historia fo.”. Ponadto „Polonica historia fo.”

56 S. Lee, Perne Andrew, w: Dictionary of National Biography, vol. 45, ed. S. Lee, London 1896, s. 10-12.

57 „The scolars at Cambridge, it was said, translated 'perno' by 'I turn, I rat, I change often'. It became proverbial to say of a coat or a cloak that had been turned that it had been Perned". Ibidem, s. 11. Najnowsze opracowanie tej ciekawej postaci: P. Collinson, Andrew Perne and His Times, w: Andrew Perne Quatercentenary Studies, ed. D. McKitterick, Cambridge 1991, s. 1-34.

58 John Dee's Library Catalogue, eds. by R.J. Roberts, A.G. Watson, London 1990.

59 The Lumley Library, eds. S. Jayne, F. Johnson, London 1956.

60 Zob. D. McKitterick, Andrew Perne and His Books, w: Andrew Perne Quatercentenary Studies, op. cit., s. $35-$ -61 .

${ }^{61}$ The Libraries of King Henry VIII, ed. James P. Carley, London 2000, “Corpus of British Medieval Library Catalogues", vol. 7, s. 126-127.
} 
w owym czasie katechizmów kard. Stanisława Hozjusza Confessio catholicae fidei Christiana, wielokrotnie występującego w księgozbiorach anglikańskich duchownych w XVI-XVII w. Szczególnie razi brak tej wrażliwości w inwentarzu Philipa Johnsona (†1576). W bibliotece tego znanego teologa, kapelana arcybiskupa Canterbury Edmunda Grindala, wśród 270 pozycji można znaleźć najważniejsze książki kontrreformacyjne, w tym np. Acta Concilii Tridentini, ale także dzieło Marcina Kromera.

Warto wspomnieć, iż wśród najbardziej uznanych autorów w Anglii, obok Hozjusza, Kopernika, Jana Łaskiego mł., znajdował się biskup poznański Wawrzyniec Goślicki i jego dzieło De optimo senatore libri duo. Wydane najpierw w Wenecji w 1568 r., potem w Bazylei w 1593 r. Przedstawia ono wzorowego męża stanu, który obok zainteresowania naukami humanistycznymi wykazuje orientację również w zasadach polityki, ekonomiki, ustroju własnego państwa oraz prawa międzynarodowego. Podnosi również kwestię odpowiedzialności władców za swoje czyny. Pod koniec XVI w. traktat został dwukrotnie przetłumaczony na angielski. Najpierw Robert Chester przetłumaczył na swój użytek księgę pierwszą. Autorem pierwszego drukowanego przekładu był znany poeta i pisarz angielski Gabriel Harvey (1545-1630). Wydane w Londynie w 1598 r. dzieło było zatytułowane The Counsellor Exactly Portraited in Two Bookes. Najprawdopodobniej dzieło spotkało się ze sprzeciwem cenzury i konfiskatą nakładu. W $1607 \mathrm{r}$. dzieło wyszło pod zmienionym tytułem A Commonwealth of Good Consaille. Przekład z 1598 r. nie wymienia nazwiska księgarza, natomiast edycja z 1607 r. została wydrukowana na zlecenie Nicholasa Linga, znanego z dwóch pierwszych edycji Hamleta Shakespeare’a z 1603 i 1604 r. Oba wydania dzieła Goślickiego zostały skonfiskowane przez cenzurę. Nie wiadomo, czy pierwsze wydanie było znane w Anglii, drugie szybko tam trafiło, o czym świadczą słowa tłumacza Gabriela Harveya w jednym z jego utworów z 1593 r., który kończy krytykę Anglii: „Jestem przekonany, że Grimaldus tak właśnie myślał o tego rodzaju senatorach, gdy pisał De optimo senatore" ${ }^{" 2}$.

W literaturze można znaleźć informację, że egzemplarz De optimo senatore został przesłany Robertowi Devereux hrabiemu Essex przez Jana Zamoyskiego lub przywieziony do Anglii przez posła Pawła Działyńskiego ${ }^{63}$. Hipoteza, że Essex mógł się zainteresować traktatem Goślickiego mogłaby wzmocnić przypuszczenia, że autor Hamleta nie tylko znał dzieło Goślickiego, lecz z niego korzystał. Tym bardziej, że znany jest bliski związek Essexa $\mathrm{z}$ hrabią Southamptonem, mecenasem Szekspira ${ }^{64}$. Dotychczasowe badania nie potwierdziły tego, choć należy wskazać na nieprzebadane jeszcze dokładnie kontakty Jana Zamoyskiego $\mathrm{z}$ angielskimi środowiskami naukowymi. Wiadomo już, że Essex posiadał wydanie weneckie dzieła Goślickiego. Zostało zakupione przez nauczyciela znanego arystokraty Roberta Wrighta w maju 1577 r. po przyjeździe do Cambridge „Grimalius De optimo Senatore"65. Świadczy o tym egzemplarz występujący w bibliotece Richarda Mote'a (†1592).

Ciekawym źródłem do historii angielskich lektur Zamoyskiego, które mogłyby pokazywać jego ściślejszy związek z Anglią, jest list do Thomasa Jamesa z lipca 1603 r., odnaleziony przez Stanisława Kota w Bibliotece Bodlejańskiej w Oksfordzie, będący recenzją

\footnotetext{
62 H. Zins, op. cit., s. 163-164.

63 Ostatnio pisano o tym w: T. Bałuk-Ulewiczowa, Goslicius' Ideal Senator and His Cultural Impact over teh Centuries: Shakespearean Reflections, Kraków 2009, s. 191-206.

64 Ibidem, s. 165.

65 R.J. Fehrenbach, E. Leedham-Green, op. cit., t. 1, s. 325.
} 
wydanej w 1600 r. książki Jamesa Ecloga Oxonio-Cartabrigiensis, tributa in libros duos; quorum prior continet catalogum confusum librorum manuscriptorum in illustrissimis bibliothecis, duarum florentissimarum Academiarum, Oxoniae et Cantabrigiae. Posterior, catalogum eorundem distinctum et dispositum secundum quatuor facultates, observato tam in nominibus, quam in operibus ipsis, alphabetico literarum ordine... Postać Jamesa i jego praca, faktycznie będąca katalogiem rękopisów bibliotecznych, jest doskonale znana. Był on organizatorem biblioteki uniwersyteckiej w Oksfordzie, która do fundacji Thomasa Bodleya była „bare and desolate room”66. Należy pamiętać, że aż do powstania British Museum w XIX w. faktycznie pełniła rolę biblioteki narodowej ${ }^{67}$. We wspomnianym liście Zamoyski prosi Jamesa o skopiowanie stron tytułowych dzieł Cycerona, których sam nie zna $^{68}$. Znany teolog Stanisław Sokołowski, wspierany przez kanclerza, zamierzał wydać Elogia clarorum virorum, czyli retoryczne sylwetki wybitnych postaci, o czym pisał do Roberta Cecila, prosząc o materiały dotyczące Anglików ${ }^{69}$. Kontakty Zamoyskiego i jego syna z Jamesem wymagają dalszych studiów ${ }^{70}$.

Pytanie najważniejsze, jaki wpływ wywarły książki polskich autorów na umysły Anglików w czasach renesansu, musi pozostać na tym etapie badań bez pełnej odpowiedzi. Niewątpliwie omówione wyżej tytuły dzieł są świadectwem uczestnictwa Polaków w kulturze europejskiej. Występują bowiem w bibliotekach angielskich najważniejsze książki polskich autorów wydane w języku wspólnym dla wykształconej Europy - po łacinie.

\section{Bibliografia}

Bałuk-Ulewiczowa T., Goslicius' Ideal Senator and His Cultural Impact over teh Centuries: Shakespearean Reflections, Kraków 2009.

Clark C., Thomas James. A Study of a Librarian, Aberystwyth 1970.

Collinson P., Andrew Perne and His Times, w: Andrew Perne Quatercentenary Studies, ed. D. McKitterick, Cambridge 1991, s. 1-34.

Fehrenbach R.J., Leedham-Green E., Private Libraries in Renaissance England. A Collection and Catalogue of Tudor and Early Stuart Book-Lists, t. 1, 1992; t. 2, 1993; t. 3, 1994; t. 4, 1995; t. 5, 1998 .

James M.R., The Western Manuscripts in the Library of Trinity College, Cambridge. A Descriptive Catalogue, vol. 2, Cambridge 1901.

Jayne S.R., Library Catalogues of the English Renaissance, Berkeley-Los Angeles 1956. John Dee's Library Catalogue, eds. R.J. Roberts, A.G. Watson, London 1990.

\footnotetext{
66 C. Clark, Thomas James. A Study of a Librarian, Aberystwyth 1970, s. 1.

67 Ibidem, s. 19.

68 S. Kot, Anglo-Polonica. Angielskie źródła rękopiśmienne do dziejów stosunków Polski z Anglją. „Nauka Polska", 20/1935, s. 82-83.

69 Ibidem, s. 82.

70 W kolekcji rękopisów Bodleian Library Ballard 44 znajdują się listy Jana Zamoyskiego i jego syna Tomasza z 1603 i 1615 r. Jak dowodzi G.W. Wheeler, oba listy nieprzypadkowo otwierały grupę listów łacińskich: „The order within each group was apparently determined by the relative importance of the writers, the first two of the letters in Latin being from John Zamoyski (1603) and his son Thomas Zamoyski (1615), successively Chancellors of Poland, while the letters of two succeeding Archbishops of Canterbury occupy the foremost places among those in English and are followed by those from the Archbiskop of York, bishops, and lesser ecclesiastical dignitaries". Letters Addressed to Thomas James First Keeper of Bodley's Library, ed. G.W. Wheeler, Oxford 1933, s. VII.
} 
Kot S., Anglo-Polonica. Angielskie źródła rękopiśmienne do dziejów stosunków Polski z Anglja, „Nauka Polska”, 20/1935, s. 49-140.

Lee S., Perne Andrew, w: Dictionary of National Biography, vol. 45, ed. S. Lee, London 1896, s. 10-12.

Leedham-Green E., Books in Cambridge Inventories: Book-lists from Vice-Chancellor's Court Probate Inventories in the Tudor and Stuart Periods, Cambridge 1986.

Leedham-Green E.S., Private Libraries in Renaissance England: A Progress Report, „The Papers of the Bibliographical Society of America", 91/1997, no 4, s. 563-571.

Letters Addressed to Thomas James First Keeper of Bodley's Library, ed. G.W. Wheeler, Oxford 1933.

McKitterick D., Andrew Perne and His Books, w: Andrew Perne Quatercentenary Studies, ed. D. McKitterick, Cambridge 1991, s. 35-61.

Szumska U., Anglia a Polska w epoce humanizmu i reformacji. Związi kulturalne, Lwów 1938, „Prace historyczno-kulturalne”, red. S. Łempicki, t. 5.

The Libraries of King Henry VIII, ed. J.P. Carley, London 2000, “Corpus of British Medieval Library Catalogues", vol. 7.

The Lumley Library, eds. S. Jayne, F. Johnson, London 1956.

Zins H., Polska w oczach Anglików, XIV-XVI wiek, wyd. 2 popr., Lublin 2002. 